DOI

\title{
ОСОБЛИВОСТІ ЗМІН МІНЕРАЛЬНОЇ ЩІЛЬНОСТІ КІСТКОВОЇ ТКАНИНИ У ХВОРИХ НА РЕВМАТОЇДНИЙ АРТРИТ В ПОЄДНАННІ 3 НЕАЛКОГОЛЬНИМ СТЕАТОГЕПАТИТОМ
}

\author{
๑С. І. Сміян, Л. В. Даньків \\ 'ДВНЗ «Тернопільський державний медичний університет імені І. Я. Горбачевського МОз України» \\ ${ }^{2}$ K3 TOP «Тернопільська університетська лікарня»
}

РЕЗЮМЕ. РА займає особливе місце серед захворювань, які призводять до розвитку остеопорозу. Остеопороз при РА $\epsilon$ наслідком як існуючого хронічного системного захворювання, так і терапії глюкокортикоїдами. Не проводилось вивчення взаємозв'язку між морфофункціональними порушеннями печінки і МЩКТ у хворих на РА.

Мета дослідження - дослідити порушення структурно-функціонального стану кісткової тканини та виявити залежність змін мінеральної щільності кісткової тканини від наявності НАГС чи його відсутності, застосовуючи рентгенівську денситометрію в пацієнтів із РА.

Матеріали та методи. Обстеження пацієнтів проводилося за традиційною методикою і включало: 1) загальноклінічні: огляд, опитування, наявність у минулому переломів, їх кількість та обставини їх виникнення, визначення IMT; 2) лабораторні (загальний та біохімічний аналіз крові, визначення РФ методом латексаглютинації, оцінку титру АТ ЦЦП методом ELISA (діагностична межа $\geq 15$ ум. од./мл); 3) мінеральну щільність кісткової тканини визначали з використанням подвійного рентгенівського денситометра ДPX-A (Dualenergy X-Ray Absorptiometry) фірми LUNAR (США) на рівні поперекового відділу хребта. У пацієнтів з МщКT на рівні поперекового відділу хребта $\leq-2,5$ SD діагностували остеопороз; у пацієнтів, у яких рівень MщKT <-1 SD i $\geq-2,5-S D-$ остеопенію; індекс Z (відхилення мінеральної щільності кістки від середнього значення у хворих відповідного віку), індекс Т (відхилення від референтного значення пікової кісткової маси у здорових осіб молодого віку); 4) статистичні.

Результати. Денситометричні показники у когорті хворих з НАСГ вказують на значне зниження МЩКТ, порівняно з пацієнтами без ураження печінки. У більшості жінок з РА та супутнім ураженням печінки у постменопаузальному періоді відзначали явища остеопенії і остеопорозу (ОП). Серед пацієнтів із мінімальною активністю РА в поєднанні з НАСГ була незначна кількість обстежених із остеопорозом, у хворих на РА II ступеня активності частка їх із остеопенією і остеопорозом розподілилася з невеликими відмінностями, хоча за відсотковим значенням переважали хворі з остеопенією. Найбільша кількість пацієнтів, яка становила групу максимальної активності РА, була представлена остеопорозом. Остеодефіцитні стани асоціювалися із ожирінням у пацієнтів з РА та НАСГ. За умов позитивності АТ ЦЦП кількість хворих із остеопорозом достовірно більша, ніж із нормальною мінеральною щільністю кісткової тканини і остеопенією. Пацієнти із серопозитивним РА мали статистично значущий вищий ризик виникнення остеодефіцитних станів і частіше хворіли на остеопороз, ніж особи із серонегативним РА. У більшої когорти хворих з РА в поєднанні з НАСГ діагностовано переломи в анамнезі: з остеопенією - у 6 (10,34\%) осі6, з остеопорозом - у 12 (20,69\%) хворих.

Висновки. Серед хворих на РА із супутнім НАСГ діагностовано явища остеопенії та остеопорозу в 87,93 \% випадків. Вивчення структурно-функціонального стану кісткової тканини поперекового відділу хребта в жінок до менопаузи і в постменопаузальному період із РА та супутнім НАСГ, порівняно з пацієнтами, які не мали супутнього ураження печінки, демонструвало достовірно вищий відсоток розвитку остеодефіцитних станів, який асоціювався із супутнім ожирінням, активністю РА, наявністю АТ ЦЦП і РФ як за кількісними значеннями МЩКТ, так й за частотою реєстрації даних станів.

КЛючОВІ СЛОВА: ревматоїдний артрит; остеопороз; остеопенія; ревматоїдний фактор (РФ); АТ ЦЦП; менопауза; ожиріння.

Вступ. За останнє десятиріччя в українській популяції відмічено тенденцію до збільшення захворювань кістково-м'язової системи, серед яких, після артрозів, ревматоїдний артрит (РА) посідає друге місце. В Україні поширеність РА становить 350 випадків на 100 тис. дорослого населення, причому хвороба вражає переважно людей працездатного віку (20-50 років), що призводить до частої і тривалої госпіталізації, а нерідко й до інвалідизації (Коваленко В. М. і співавт., 2010). РА займає особливе місце серед захворювань, які призводять до розвитку остеопорозу (MacLean C. et al., 2014). Остеопороз при цій патології $\epsilon$ наслідком як існуючого хронічного системного захво- рювання, так і терапії глюкокортикоїдами (ГК) (Корж Н. А. і співавт., 2012 ). Особливе значення для розвитку остеопорозу при РА, крім загальних факторів ризику (вік, стать, тривалість менопаузи у жінок, спадковість, вплив на кісткову тканину лікарських засобів тощо), мають фактори, які асоційовані власне із захворюванням (Гукасян Д. А. і співавт., 2015 ). Це насамперед хронічне запалення, його тривалість, активність, зниження функціонального статусу хворих (Нейко Є. М. і співавт., 2013). Клінічне значення остеопорозу в першу чергу визначається високим ризиком переломів кісток скелета, що суттєво знижує якість життя і погіршує прогноз у хворих на PA (Kanis J. A. et al., 
Огляди літератури, оригінальні дослідження, погляд на проблему

2012; Boonen S. et al., 2015). На сьогоднішній день остаточно не встановлені фактори ризику розвитку остеопорозу та його ускладнень, не визначено частоту та структуру остеопоротичних переломів при РА (Поворознюк В. В. і співавт., 2011). Не проводилось вивчення взаємозв'язку між морфофункціональними порушеннями печінки і МЩКТ у хворих на ревматоїдний артрит. Не розроблено диференційованого підходу до діагностики, профілактики, лікування остеопорозу та його ускладнень при РА у хворих з супутнім неалкогольним стеатогепатитом.

Мета - дослідити порушення структурнофункціонального стану кісткової тканини та виявити залежність змін мінеральної щільності кісткової тканини від наявності НАГС чи його відсутності, застосовуючи рентгенівську денситометрію в пацієнтів із РА.

Матеріал і методи дослідження. Для здійснення поставленої мети проведено комплексне дослідження, в якому взяли участь 123 хворих на PA, переважно жінки - 102 (82,9 \%) в постменопаузальному періоді, в тому числі - 58 (47,15 \%) пацієнтів з РА, ускладненим НАГС та 65 (52,85 \%) осіб з РА без супутнього ураження печінки. Групи хворих були зіставні між собою за основними ознаками (менопауза, ступінь активності, наявність АТ ЦЦП, РФ, наявність переломів в анамнезі, IMT). Діагноз РА встановлювали у відповідності з критеріями Американської ревматологічної асоціації (ACR/EULAR 2010). В усіх випадках НАСГ було діагностовано після РА. Обстеження пацієн- тів проводили за традиційною методикою, що включала: 1) загальноклінічні дослідження: огляд, опитування, наявність у минулому переломів, з'ясування їх кількості та обставин виникнення, визначення IMT; 2) лабораторні дослідження - загальний та біохімічний аналіз крові, визначення РФ методом латекс-аглютинації, оцінку титру АT ЦЦП методом ELISA (діагностична межа $\geq 15$ ум. од./мл); 3) мінеральну щільність кісткової тканини визначали з використанням подвійного рентгенівського денситометра ДРХ-A (Dualenergy X-Ray Absorptiometry) фірми LUNAR (США) на рівні поперекового відділу хребта. У пацієнтів 3 МЩКТ на рівні поперекового відділу хребта $\leq-2,5$ SD, діагностували остеопороз; у пацієнтів, у яких рівень МЩКТ був < -1 SD і $\geq-2,5$ - SD-остеопенію; індекс Z (відхилення мінеральної щільності кістки від середнього значення у хворих відповідного віку), індекс Т (відхилення від референтного значення пікової кісткової маси у здорових осіб молодого віку); 4) статистичні методи дослідження.

Результати й обговорення. Оцінка показників денситометрії у когорті хворих з НАСГ свідчила про значне зниження МЩКТ, порівняно з пацієнтами без супутнього ураження печінки (табл. 1).

3 огляду на вагоме значення постменопаузи, імунозапальних реакцій у виникненні ОП як у загальній популяції, так і за умов РА зокрема, в подальшому провели аналіз частоти остеопенії і ОП у обстежених пацієнтів (табл. 2). Встановлено, що у пацієнток в постменопаузі остеодефіцитні стани зареєстровані частіше в обох групах, але за умов

Таблиця 1. Оцінка мінеральної щільності кісткової тканини у хворих на РА в поєднанні з НАСГ і без ураження печінки

\begin{tabular}{|l|c|c|}
\hline \multicolumn{1}{|c|}{ Показники } & Хворі без ураження печінки & Хворі з НАСГ \\
\hline MЩКT (L1-L4), BMD, г/см2 & $1,095 \pm 0,19$ & $0,878 \pm 0,18^{*}$ \\
\hline $\mathrm{T}$ & $-0,87 \pm 0,21$ & $-1,43 \pm 0,15^{*}$ \\
\hline $\mathrm{Z}$ & $-1,12 \pm 0,32$ & $-2,65 \pm 0,13^{*}$ \\
\hline
\end{tabular}

Примітка. * - вірогідно зменшені показники в порівнянні з групою без ураження печінки, p<0,05.

Таблиця 2. Поширеність остеопенічного синдрому та остеопорозу у хворих на РА з врахуванням менопаузи у жінок, ступеня активності, наявності АТ ЦЦП, РФ, ожиріння та переломів в анамнезі

\begin{tabular}{|c|c|c|c|}
\hline Показники & $\begin{array}{c}\text { Нормальна МЩКТ } \\
\text { n (\%) }\end{array}$ & $\begin{array}{c}\text { Остеопенія } \\
\text { n (\%) }\end{array}$ & $\begin{array}{c}\text { Остеопороз } \\
\text { n (\%) }\end{array}$ \\
\hline 1 & 2 & 3 & 4 \\
\hline \multicolumn{4}{|c|}{ Хворі з ураженням печінки } \\
\hline Жінки до менопаузи & $5(8,62 \%)$ & $12(20,69 \%)$ & $6(10,34 \%)$ \\
\hline Жінки в постменопаузальному періоді & $3(5,17 \%)$ & $9(15,52 \%)$ & $14(24,14 \%)$ \\
\hline \multicolumn{4}{|c|}{ Хворі без ураження печінки } \\
\hline Жінки до менопаузи & $18(27,69 \%)$ & $9(13,85 \%)$ & $2(3,08 \%)$ \\
\hline Жінки в постменопаузальному періоді & $13(20,00 \%)$ & $7(10,77 \%)$ & $4(6,15 \%)$ \\
\hline
\end{tabular}




\begin{tabular}{|c|c|c|c|}
\hline 1 & 2 & 3 & 4 \\
\hline \multicolumn{4}{|c|}{ Хворі з ураженням печінки } \\
\hline І ступінь активності & $4(6,90 \%)$ & $4(6,90 \%)$ & $3(5,17 \%)$ \\
\hline II ступінь активності & $3(5,17 \%)$ & $14(24,14 \%)$ & $12(20,69 \%)$ \\
\hline III ступінь активності & $0(0 \%)$ & $3(5,17 \%)$ & $15(25,86 \%)$ \\
\hline \multicolumn{4}{|c|}{ Хворі без ураження печінки } \\
\hline I ступінь активності & $11(16,92 \%)$ & $3(4,62 \%)$ & $2(3,08 \%)$ \\
\hline II ступінь активності & $25(38,46 \%)$ & $8(12,31 \%)$ & $4(6,15 \%)$ \\
\hline III ступінь активності & $4(6,15 \%)$ & $5(7,69 \%)$ & $3(4,62 \%)$ \\
\hline \multicolumn{4}{|c|}{ Хворі з ураженням печінки } \\
\hline АТ ЦЦП (+) & $9(15,52 \%)$ & $13(22,41 \%)$ & $20(34,48 \%)$ \\
\hline \multicolumn{4}{|c|}{ Хворі без ураження печінки } \\
\hline АТ ЦЦП (+) & $3(4,62 \%)$ & $7(10,77 \%)$ & $10(15,38 \%)$ \\
\hline \multicolumn{4}{|c|}{ Хворі з ураженням печінки } \\
\hline $\mathrm{P \Phi}(+)$ & $8(13,79 \%)$ & $12(20,69 \%)$ & $16(27,59 \%)$ \\
\hline \multicolumn{4}{|c|}{ Хворі без ураження печінки } \\
\hline$P \Phi(+)$ & $13(20,00 \%)$ & $17(26,15 \%)$ & $10(15,39 \%)$ \\
\hline \multicolumn{4}{|c|}{ Хворі з ураженням печінки } \\
\hline Переломи в анамнезі (+) & $0(0 \%)$ & $6(10,34 \%)$ & $12(20,69 \%)$ \\
\hline \multicolumn{4}{|c|}{ Хворі без ураження печінки } \\
\hline Переломи в анамнезі (+) & $0(0 \%)$ & $1(1,54 \%)$ & $3(4,61 \%)$ \\
\hline \multicolumn{4}{|c|}{ Хворі з ураженням печінки } \\
\hline Ожиріння (+) & $7(12,07 \%)$ & $13(22,41 \%)$ & $17(29,31 \%)$ \\
\hline \multicolumn{4}{|c|}{ Хворі без ураження печінки } \\
\hline Ожиріння (+) & $4(6,15 \%)$ & $7(10,77 \%)$ & $8(12,31 \%)$ \\
\hline
\end{tabular}

Таблиця 3. Показники мінеральної щільності кісткової тканини у хворих на ревматоїдний артрит, залежно від наявності менопаузи у жінок і ступеня активності за даними рентгенівської денситометрії

\begin{tabular}{|c|c|c|c|}
\hline Показники & $\begin{array}{c}\text { МЩКТ, BMD } \\
\Gamma / \mathrm{CM}^{2}\end{array}$ & $\mathrm{~T}$ & Z \\
\hline \multicolumn{4}{|c|}{ Жінки до менопаузи } \\
\hline Хворі без ураження печінки & $1,08 \pm 0,03$ & $-0,82 \pm 0,22$ & $-0,46 \pm 0,18$ \\
\hline Хворі з НАСГ & $0,86 \pm 0,07^{*}$ & $-1,84 \pm 0,30 *$ & $-1,39 \pm 0,07^{*}$ \\
\hline \multicolumn{4}{|c|}{ Жінки в постменопаузальному періоді } \\
\hline Хворі без ураження печінки & $0,98 \pm 0,10$ & $-1,49 \pm 0,28$ & $-1,28 \pm 0,27$ \\
\hline Хворі з НАСГ & $0,82 \pm 0,06^{*}$ & $-2,96 \pm 0,27^{*}$ & $-2,21 \pm 0,13^{*}$ \\
\hline \multicolumn{4}{|c|}{ Активність РА, ступінь } \\
\hline \multicolumn{4}{|c|}{ Хворі без ураження печінки } \\
\hline І ступінь активності & $1,16 \pm 0,03$ & $-0,12 \pm 0,06$ & $-0,56 \pm 0,12$ \\
\hline ІІ ступінь активності & $1,01 \pm 0,05$ & $-0,46 \pm 0,09$ & $-0,98 \pm 1,03$ \\
\hline III ступінь активності & $0,93 \pm 0,02$ & $-1,12 \pm 1,01$ & $-1,34 \pm 1,15$ \\
\hline \multicolumn{4}{|c|}{ Хворі з НАСГ } \\
\hline І ступінь активності & $1,12 \pm 0,15^{*}$ & $-0,38 \pm 0,34^{*}$ & $-0,48 \pm 0,03^{*}$ \\
\hline II ступінь активності & $0,97 \pm 0,06 *$ & $-1,24 \pm 0,08 *$ & $-1,36 \pm 0,23 *$ \\
\hline III ступінь активності & $0,85 \pm 0,13 *$ & $-2,92 \pm 0,12 *$ & $-2,86 \pm 0,17^{*}$ \\
\hline
\end{tabular}

Примітка. *-достовірне значення щодо групи хворих на РА без ураження печінки. 
Огляди літератури, оригінальні дослідження, погляд на проблему

наявності НАСГ кількість жінок з ОП переважала втричі. Аналогічні дані отримані при аналізі кількості пацієнток з остеопенією і ОП залежно від активності РА, де переважна більшість обстежених з ОП була з високим ступенем активності запального процесу і з супутнім НАСГ.

Відомо, що агресивність перебігу РА зумовлена наявністю АТ ЦЦП і РФ, тому ми провели порівняльний аналіз поширеності остеодефіциту залежно від факту позитивності за даними показниками. Встановлено, що серед пацієнтів з супутнім НАСГ із наявністю АТ ЦЦП і РФ вірогідно більша частка діагностованої остеопенії і ОП. Серед пацієнток з НАСГ частіше констатоване ожиріння і кількість переломів в анамнезі майже в 5 разів більша.

В подальшому ретельний аналіз кількісних значень стану МЩКТ у жінок в постменопаузі показав вірогідне їх зменшення, особливо за умов наявності НАСГ. Показники мінеральної щільності кісткової тканини у хворих на РА від- повідно до ступеня активності свідчили про те, що серед обстежених із РА за умов II і III ступенів активності найбільша частка була представлена хворими з остеопенією без ураження печінки, а остеопороз діагностовано серед обстежених із РА III ступеня активності в поєднанні з НАСГ (табл. 3).

Висновки. 1. Серед хворих на РА із супутнім НАСГ діагностовано явища остеопенії та остеопорозу в 87,93 \% випадків.

2. Вивчення структурно-функціонального стану кісткової тканини поперекового відділу хребта в жінок з РА до менопаузи і в постменопаузальному періоді з супутнім НАСГ, порівняно з пацієнтами, які не мали супутнього ураження печінки, продемонструвало достовірно вищий відсоток розвитку остеодефіцитних станів, який асоціювався із супутнім ожирінням, активністю РА, наявністю АТ ЦЦП і РФ як за кількісними значеннями МЩКТ, так і за частотою реєстрації даних станів.

\section{ЛІТЕРАТУРА}

1. Изучение взаимосвязи между минеральной плотностью костной ткани и клинико-лабораторными показателями активности ревматоидного артрита / Д. А. Гукасян, Р. М. Балабанова, А. В. Смирнов, Е. Л. Насонов // Ревматология. - 2015.- N 1.- С. 18-21

2. Демографія і стан здоров'я народу України : аналітично-статистичний посібник / за ред. В. М. Коваленка, В. М. Корнацького - Київ, 2010. - 143 с.

3. Остеопороз: эпидемиология, клиника, диагностика, профилактика и лечение / Н. А. Корж, В. В. Поворознюк, Н. В. Дедух, И. А. Зупанец. - Харьков : Золотые страницы, 2012. -646 с.

4. Нейко Є. М. Особливості перебігу та лікування остеопорозу у хворих на ревматоїдний артрит / Є. М. Нейко, Р. І. Яцишин // Укр. ревматол. журн. - 2013. - T. 29, № 3. - C. 82-83.

\section{REFERENCES}

1. Hukasyan, D.A., Balabanova, R.M., Smyrnov, A.V., \& Nasonov, E.L. (2015). Izuchenye vzaimosvyazi mezhdu mineralnoy plotnostyu kostnoy tkani i klinikolaboratornymi pokazatelyamy aktivnosty revmatoydnogo artrita [A study of the relationship between bone mineral density and clinical and laboratory indices of rheumatoid arthritis activity]. Revmatologiia - Reumatology, 1, 18-21 [in Russian].

2. Kovalenko, V.M., \& Kornatskyi, V.M. (Eds.) (2010). Demohrafiya i stan zdorovia narodu Ukrayiny: analitychnostatystychnyi posibnyk [Demographics and the state of health for the people of Ukraine: analytical and statistical manual]. Kyiv [in Ukrainian].

5. Поворознюк В. В. Роль FRAX в прогнозировании риска переломов / В. В. Поворознюк, Н.В.Григорьева // Боль. Суставы. Позвоночник. - 2011. - № 2. - С. 19-28.

6. Effect of osteoporosis treatments on risk of non-vertebral fractures: review and meta-analysis of intention-to-treat studies / S. Boonen, R. F. Laan, I. S. Barton, N. B. Watts // Osteoporos. Int. - 2015. - № 16. -P. 1291-1298.

7. FRAX $®$ with and with out bone mineral density / J. A. Kanis, E. McCloskey, H. Johansson [et al.] // Calcif. Tissue Int. - 2012. - № 1. - P. 1-13.

8. Systematic review: comparative effectiveness of treatments to prevent fractures in men and women with low bone density orosteoporosis / C. Mac Lean, S. Newberry, M. Maglione [et al.] // Ann. Intern. Med. 2014. - № 148. - P. 197-213.

3. Korzh, N.A., Povoroznyuk, V.V., Dedukh, N.V., \& Zupanets, Y.A. (2012). Osteoporoz: epidemiologiya, klinika, diagnostika, profilaktika i lechenie [Osteoporosis: epidemiology, clinical picture, diagnosis, prevention and treatment]. Kharkov: "Zolotye Stranitsy" [in Russian].

4. Neyko, Ye.M., \& Yatsyshyn, R.I. (2013). Osoblyvosti perebihu ta likuvannya osteoporozu u khvorykh na revmatoidnyi artryt [Features of the course and treatment of osteoporosis in patients with rheumatoid arthritis]. Ukr. revmatol. zhurn. - Ukrainian Rheumatoid Journal, 29 (3), 8283. [in Ukrainian].

5. Povoroznyuk, V.V., \& Grygoreva, N.V. (2011). Rol FRAX $v$ prognozirovanii riska perelomov [The role of 
Огляди літератури, оригінальні дослідження, погляд на проблему

FRAX in predicting the risk of fractures]. Bol. Sustavy. Pozvonochnik - Pain. Joints. Backbone, 2, 19-28 [in Russian].

6. Boonen, S., Laan, R.F., Barton, I.P., \& Watts, N.B. (2015). Effect of osteoporosis treatments on risk of nonvertebral fractures: review and meta-analysis of intentionto-treat studies. Osteoporos Int., 16, 1291-1298.

7. Kanis, J.A., McCloskey, E., \& Johansson, H. (2012).
FRAX $\circledast$ with and with out bone mineral density. Calcif. Tissue Int., 1, 1-13.

8. Mac Lean, C., Newberry, S., \& Maglione, M. (2104). Systematic review: comparative effectiveness of treatments to prevent fractures in men and women with low bone density orosteoporosis. Ann. Intern. Med., 148, 197-213.

\title{
ОСОБЕННОСТИ ИЗМЕНЕНИЙ МИНЕРАЛЬНОЙ ПЛОТНОСТИ КОСТНОЙ ТКАНИ У БОЛЬНЫХ РЕВМАТОИДНИМ АРТРИТОМ В СОЧЕТАНИИ С НЕАЛКОГОЛЬНЫМ СТЕАТОГЕПАТИТОМ
}

\author{
ФС. И. Смиян ${ }^{1}$, Л. В. Данькив² \\ ${ }^{1}$ ВУз «Тернопольский государственный медицинский университет имени И. Я. Горбачевского \\ МОЗ Украчны» \\ ${ }^{2}$ КЗ ТОС «Тернопольская университетская больница»
}

РЕЗЮМЕ. РА занимает особое место среди заболеваний, приводящих к развитию остеопороза. Остеопороз при РА является следствием как существующего хронического системного заболевания, так и терапии глюкокортикоидами. Не проводилось изучение взаимосвязи между морфофункциональными нарушениями печени и МЩКТ у больных РА.

Цель исследования - исследовать нарушения структурно-функционального состояния костной ткани и выявить зависимость изменений минеральной плотности костной ткани от наличия НАГС или его отсутствия, применяя рентгеновскую денситометрию у пациентов с РА.

Материалы и методы. Обследование пациентов проводилось по традиционной методике и включало: 1) общеклинические: осмотр, опрос, наличие в прошлом переломов, их количество и обстоятельства их возникновения, определение ИМТ; 2) лабораторные (общий и биохимический анализ крови, определение РФ методом латекс-агглютинации, оценку титра AT ЦЦП методом ELISA (диагностический предел $\geq 15$ ум. ед./мл); 3) минеральную плотность костной ткани определяли с использованием двойного рентгеновского денситометра ДPX-A (Dualenergy X-Ray Absorptiometry) фирмы LUNAR (CША) на уровне поясничного отдела позвоночника. У пациентов МПКТ на уровне поясничного отдела позвоночника $\leq-2,5$ SD диагностировали остеопороз; у пациентов, у которых уровень МПКТ <-1 SD и $\geq-2,5$ SD-остеопению; индекс Z (отклонение минеральной плотности кости от среднего значения у больных соответствующего возраста), индекс Т (отклонение от референтного значения пиковой костной массы у здоровых лиц молодого возраста); 4) статистические.

Результаты. Денситометрические показатели в когорте больных с НАСГ указывают на значительное снижение МПКТ в сравнении с пациентами без поражения печени. У большинства женщин, больных на РА с сопутствующим поражением печени, в постменопаузальном периоде отмечали явления остеопении и остеопороза (ОП). Среди пациентов с минимальной активностью РА в сочетании с НАСГ было незначительное количество обследованных с остеопорозом, у больных РА ІІ степени активности доля их с остеопенией и остеопорозом распределилась с небольшими отличиями, хотя по процентному значению преобладали больные с остеопенией. Наибольшее количество пациентов, которые составили группу максимальной активности РА, было с остеопорозом. Остеодефицитное состояние ассоциировались с ожирением у пациентов РА с НАСГ. По условиям положительности АТ ЦЦП количество больных с остеопорозом достоверно больше, чем с нормальной минеральной плотностью костной ткани и остеопенией. Пациенты с серопозитивным РА имели статистически значимый высокий риск возникновения остеодефицитных состояний и чаще болели остеопорозом, чем с серонегативным РА. У большей когорты больных РА в сочетании с НАСГ диагностированы переломы в анамнезе: с остеопенией у $6(10,34 \%)$ человек, с остеопорозом - $12(20,69 \%)$ больных.

Выводы. Среди больных РА с сопутствующим НАСГ диагностировано явления остеопении и остеопороза В 87,93 \% случаев. Изучение структурно-функционального состояния костной ткани поясничного отдела позвоночника у женщин сРА до менопаузы и в постменопаузальном периоде с сопутствующим НАСГ, по сравнению с пациентами, которые не имели сопутствующего поражения печени, продемонстрировало достоверно высший процент развития остеодефицитных состояний, которые ассоциировались с сопутствующим ожирением, активностью РА, наличием АТ ЦЦП и РФ как по количественными значениями МПКТ, так и по частоте регистрации данных состояний.

КЛЮЧЕВЫЕ СЛОВА: ревматоидный артрит; остеопороз; остеопения; ревматоидный фактор (РФ); АТ ЦЦП; менопауза; ожирение. 


\title{
Огляди літератури, оригінальні дослідження, погляд на проблему \\ FEATURES OF CHANGES OF MINERAL BONE DENSITY IN PATIENTS WITH RHEUMATORY ARTHRITIS IN COMBINATION WITH NONALCOHOLIC STEATOHEPATITIS
}

\author{
@S. I. Smiyan', L. V. Dankiv² \\ 11. Horbachevsky Ternopil State Medical University \\ ${ }^{2}$ Communal Ternopil Regional Council "Ternopil University Hospital"
}

\begin{abstract}
SUMMARY. RA has a special place among the diseases leading to the development of osteoporosis. Osteoporosis in RA is a consequence of the existing chronic systemic disease, and therapy with glucocorticoids. There wasn't conducted of the study relationship between morphological and functional disorders of the liver and BMD in patients with RA.

The aim of the study - to investigate violations of structural-functional state of bone tissue and to identify the dependence of changes of mineral density of bone tissue from the presence of NASH, or lack there of, using $\mathrm{x}$-ray densitometry in patients with RA.

Materials and Methods. Examination of patients was carried out according to traditional methods and included: 1 ) the general clinical: examination, survey, history of fractures, their number and the circumstances of their occurrence, determination of BMD; 2) laboratory (General and biochemical blood analysis, determination of RF by latex agglutination, the assessment of the titer of anti-CCP by ELISA (diagnostic limit $\geq 15$ mind. units $/ \mathrm{ml}$ ); 3 ) mineral density of bone tissue was determined using dual $x$-ray densitometer DRG-A (Dualenergy X-Ray Absorptiometry) of the firm LUNAR (USA) at the level of the lumbar spine. Patients BMD at the level of the lumbar spine $\leq-2.5$ SD, was diagnosed with osteoporosis; patients in whom the level of BMD <-1 SD and $\geq-2.5$ SD osteopeny; index Z (deviation of bone mineral density from the mean value in patients of appropriate age), $T$ (deviation from the reference values for peak bone mass in healthy young adults); 4) statistical.

Results. Densitometric indicators in a cohort of patients with NASH show a significant decrease BMD in comparison with patients without liver damage. The majority of women in RA with concomitant liver in postmenopausal period have noted the phenomenon of osteopenia and osteoporosis (OP). Among patients with minimal activity of RA in combination with NASH had a small number of the examined women with osteoporosis, patients with rheumatoid arthritis II degree of activity their share with osteopenia and osteoporosis were distributed with small differences, although the percentage was dominated by patients with osteopenia. The greatest number of patients, which amounted to a group of maximum RA activity, was presented with osteoporosis. Osteogenic conditions was associated with obesity in RA patients with NASH. Under the terms of the positivity of anti-CCP the number of patients with osteoporosis was significantly higher than with normal mineral bone density and osteopenia. Patients with seropositive RA had a statistically significant high risk of osteogenic conditions and often suffered from osteoporosis than those with seronegative RA. In a larger cohort of patients with RA in combination with NASH was diagnosed with fractures in anamnesis: osteopenia 6 (10.34\%) patients, of osteoporosis - 12 (20.69\%) of patients.

Conclusions. Thus, it is demonstrated that among patients with RA with concomitant fatty liver disease was diagnosed phenomena osteopenia and osteoporosis in $87.93 \%$ of cases. The study of structural-functional state of bone tissue of the lumbar spine in women with RA before menopause and in postmenopausal period with concomitant fatty liver disease was compared with patients who had concomitant liver showed a significantly higher percentage of development osteogenic states, which was associated with concomitant obesity, activity of RA, the presence of anti-CCP and RF quantitative values and frequency of data recording conditions.
\end{abstract}

KEY WORDS: rheumatoid arthritis; osteoporosis; osteopenia; rheumatoid factor (RF); anti-CCP; menopause; obesity.

Отримано 20.02.2017 